\title{
Spectrophotometric method for the determination of tolnaftate in pharmaceutical preparations
}

\author{
Nief Rahman Ahmed \\ Department of Environmental Technology \\ College of Environment \\ University of Mosul
}

Nawfal Sheet Mohamad

Department of Chemistry

College of Education

University of Mosul
Received
$19 / 05 / 2013$
Accepted

04 / 09 / 2013

\section{الخلاصة}

تم تطوير طريقة طيفية بسيطة وسريعة وذات حساسية و دقة عالية لتقدير التولنافتيت في صورته النقية وفي مستحضراته الصيدلانية. تعتمد الطريقة على أكسدة التولنافتيت بواسطة

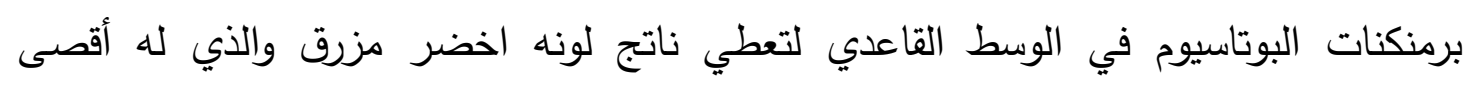

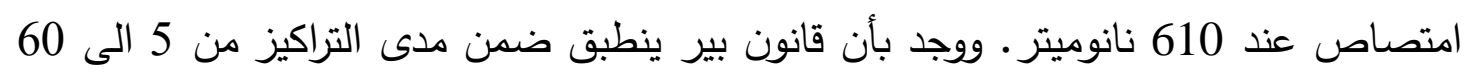

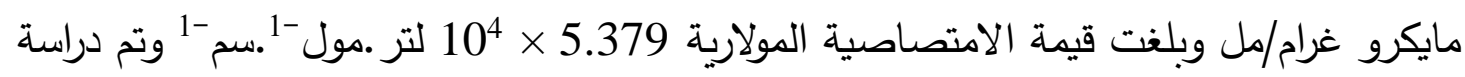
الظروف المثلى للتفاعل وطبقت الطريقة بنجاح لتقدير التولنافتيت في بعض مض مستحضراته الصيدلانية. وتم إجراء مقارنة إحصائية بين نَتائجج هذه الطريقة ونتائج الطريقِة القياسية الدستورية

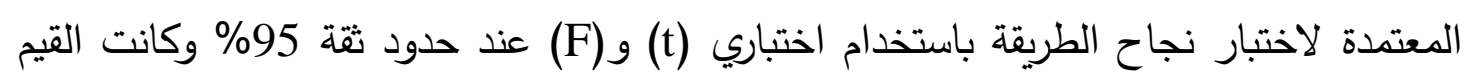

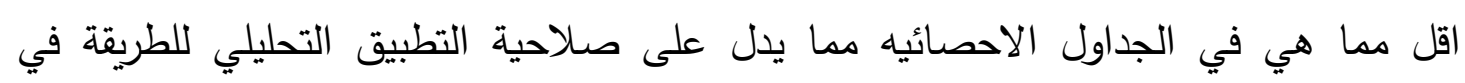

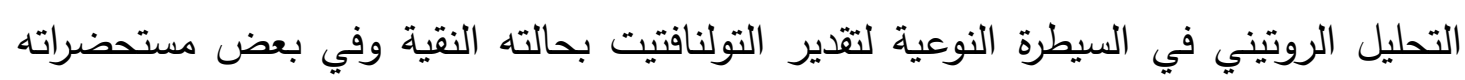
الصيدلانية كما وجد عدم وجود تداخل للمضافات الدوائية في ألطريقه المقترحة.

\begin{abstract}
A simple, accurate, rapid and sensitive visible spectrophotometric method has been developed for the determination of tolnaftate in pure and pharmaceutical preparations. The method is based on the reaction of tolnaftate with potassium permanganate in alkaline medium to form a bluish green colored product with an absorption maximum at $610 \mathrm{~nm}$. Beer's law was obeyed in the range of $5-60 \mu \mathrm{g} / 25 \mathrm{ml}$ with a molar absorbitivity of $5.379 \times 10^{4} \mathrm{~L} . \mathrm{mol}^{-1} \cdot \mathrm{cm}^{-1}$. The optimum conditions for all color development were described and the proposed method has been
\end{abstract}


successfully applied for the determination of tolnaftate in pharmaceutical preparations. A statistical comparison of these results with those of official method using ( $t$ and $F$ ) values at $95 \%$ confidence level, The calculated $\mathrm{t}-$ and $\mathrm{F}$ - values did not exceed the theoretical values indicating that there was no significant differences between the precision of the proposed and official method. So that the proposed method can be used as a routine quality control for determination of tolnaftate in pure form and in pharmaceutical formulations. The common excipients and additives did not interfere in the proposed method.

Keywords: Tolnaftate, Potassium permangnate, Spectrophotometric

\section{Introduction}

Tolnaftate is $O$-2-naphthyl methyl(3-methylphenyl) thiocarbamate, and has the followino chemical ctructure.-<smiles>Cc1cccc(N(C)C(=S)Oc2ccc3ccccc3c2)c1</smiles>

$\mathrm{C}_{19} \mathrm{H}_{17} \mathrm{NOS}=307.4 \mathrm{~g} / \mathrm{mol}$.

Tolnaftate is an antifungal and used topically in the treatment of cutaneous disease such as jock itch, athlete's foot [1,2], the other skin infections due to, epidermophyton, Microsporum, Trichophyton species, and Malasseziafurfur. [3,4]. The analytical methods used for tolnaftate assay in pharmaceutical formulations mainly employ high performance liquid chromatography (HPLC) [5-9] and (HPTLC) [10]. USP 33 and Bp (2013) prescribes UV spectrophotomeric determination of tolnaftate in cream and gel at $258 \mathrm{~nm}$ after appropriate extraction.[11,12], a survey of literature revealed that only a few visible spectrophotometric methods were reported [13-15] and spectrofluorimetry method has been also used [16]. The present method described a simple, economical, accurate, sensitive and reproducible spectrophotometric method for the determination of tolnaftate in pharmaceutical preparations. The method based on the oxidation of tolnaftate by a potassium permanganate in alkaline solution to form a bluish green colored product with an maximum absorption at $610 \mathrm{~nm}$.

\section{EXPERIMENTAL}

\section{Apparatus}

Optima sp-3000 plus UV-visible spectrophotometer with $1.0 \mathrm{~cm}$ quartz cells were used for all absorption measurements.

\section{Reagents}


All chemicals used were of analytical reagent grade. A standard solution of tolnaftate $(100 \mathrm{ppm})$ was prepared by dissolving $0.0100 \mathrm{~g}$ of pure drug in $100 \mathrm{~mL}$ ethanol. It was later diluted with water to get concentration of $10 \mathrm{ppm}$. Potassium permanganate about $0.01 \mathrm{M}$. This solution was prepared by dissolving $1.6 \mathrm{~g}$ in $1 \mathrm{~L}$ distilled water, Then the solution was heated to boiling and then filtered through asbestos. The filtered solution should be kept in the dark and standardized immediately before use. [17]. Sodium hydroxide $(2 \mathrm{~N})$. This solution was prepared by dissolving $8 \mathrm{~g}$ of pure $\mathrm{NaOH}$ in $100 \mathrm{ml}$ distilled water.

\section{Recommended procedures}

Different aliquots of standard tolnaftate solution equivalent to 5$60 \mu \mathrm{g}$ were transferred into a series of $25 \mathrm{ml}$ volumetric flask, $5 \mathrm{ml}$ of $2 \mathrm{~N}$ $\mathrm{NaOH}$ and $3 \mathrm{ml}$ of $0.01 \mathrm{M} \mathrm{KMnO}_{4}$ were added. The content was mixed and let stand for 5 min with occasional shaking. The volume was diluted to the mark with distilled water and mixed well. The absorbance of each solution was measured at $610 \mathrm{~nm}$ against a reagent blank.

\section{Procedures for pharmaceutical preparations: Creams:}

$1 \mathrm{gm}$ of cream, equivalent to $10 \mathrm{mg}$ of tolnaftate was transferred to $250 \mathrm{ml}$ separating funnel containing $75 \mathrm{ml}$ chloroform. The chloroform solution successively washed with two portions $(25 \mathrm{ml})$ of $0.1 \mathrm{~N} \mathrm{NaOH}$, two $25 \mathrm{ml}$ portions of $0.1 \mathrm{~N} \mathrm{HCl}$ and $25 \mathrm{ml}$ of water. The chloroform layer was filtered through a chloroform-washed cotton pledged into a $100 \mathrm{ml}$ volumetric flask. Chloroform was added to volume, and mixed, $10 \mathrm{ml}$ of chloroform solution was evaporated on a steam bath just to dryness and the residue was dissolved in $20 \mathrm{ml}$ of ethanol and diluted to $100 \mathrm{ml}$ with ethanol [11], $3 \mathrm{ml}$ of this solution was treated as mentioned under recommended procedure.

\section{Topical solutions:}

A $1.0 \mathrm{ml}$ of solution containing $10 \mathrm{mg}$ of tolnaftate was transferred into100 $\mathrm{mL}$ volumetric flask and diluted up to mark with ethanol,3ml of this solution was treated as mentioned under recommended procedure.

\section{Results and Discussions}

The reaction between tolnaftate and $\mathrm{KMnO}_{4}$ in alkaline medium yields a green color dye due to the formation of manganate ions, which have maximum absorption at $610 \mathrm{~nm}$ Fig.(1).

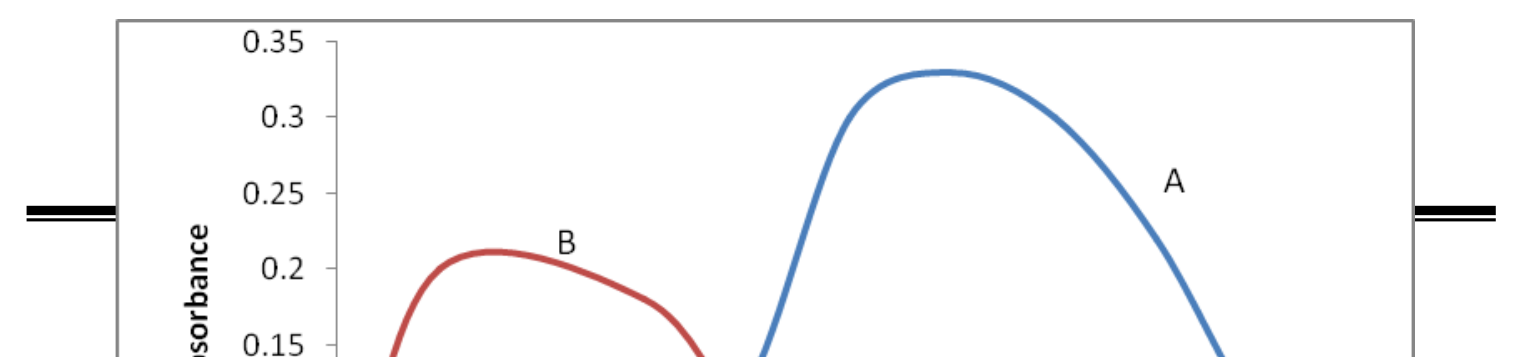


Fig(1):Absorption spectra of (A) -Tolnaftate $(40 \mu \mathrm{g} / 25 \mathrm{ml})$ withKMnO $\mathrm{O}_{4}$ against blank. (B) - Blank against distilled water.

The various experimental parameters affecting the development and stability of the reaction product was optimized by changing each variable in turn while keeping all other variables constant.

\section{Effect of $\mathrm{KMnO}_{4}$ concentration}

The absorbance increase with increasing $\mathrm{KMnO}_{4}$ concentration. It was found that $3 \mathrm{ml}$ of $0.01 \mathrm{M} \mathrm{KMnO}_{4}$ was adequate for the maximum absorbance for the dye formed.

\section{Effect of $\mathrm{NaOH}$}

Trials were made to determine the drug through oxidation with $\mathrm{KMnO}_{4}$ in neutral, acidic and alkaline media, oxidation of tolnaftate was observed in alkaline medium $(\mathrm{NaOH})$ compaired with neutral and acidic mediums. It was found that increasing the volume of $2 \mathrm{M} \mathrm{NaOH}$ would increase absorbance of the reaction product up to $5 \mathrm{ml}$. after that $\mathrm{NaOH}$ has no effect on the absorbance, therefore $5 \mathrm{ml}$ was selected for the subsequent experiments.

\section{Effect of temperature}

The resulting product of the proposed method was studied at room temperature $\left(25 \pm 5 \mathrm{C}^{0}\right)$, Higher temperature causes turbid color, therefore, room temperature was selected as a suitable temperature.

\section{Effect of reaction time}

The color formed immediately after addition of potassium permanganate and became stable after 5 minutes, therefore 5 minutes as a development time was selected as a suitable time in the recommended procedure, the color obtained was stable for at least 3 hours.

\section{Order of addition}


To test the order of addition on the absorbance of the product, different orders were tested. The selected order was sample solution, $\mathrm{NaOH}$ followed by $\mathrm{KMnO}_{4}$ solution which was gave high absorbance value.

\section{Calibration graph}

Employing the conditions described in the recommended procedure a linear calibration graph of tolnaftate is obtained Fig.(2), which shows that Beer's law is obeyed over the concentration range $5-60 \mu \mathrm{g} / 25 \mathrm{ml}$ with determination coefficient of 0.999 , intercept of 0.016 and slope of 0.007 .

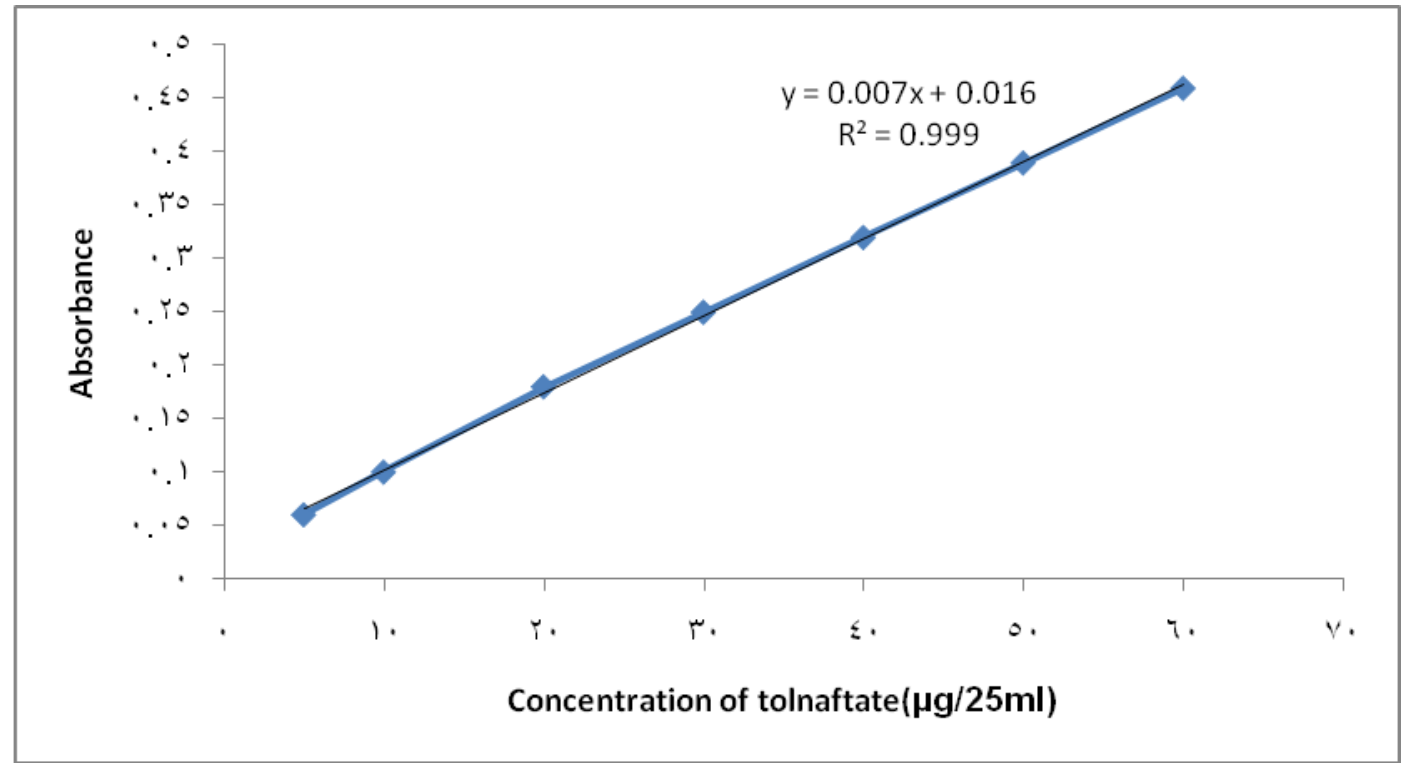

Fig. (2): Calibration curve for tolnaftate

The limits of detection (LOD) and quantification (LOQ) were calculated using the following formulae: $\mathrm{LOD}=(3.3 \sigma / \mathrm{s})$ and $\mathrm{LOQ}=(10$ $\sigma / \mathrm{s})$ where $\sigma$ is the standard deviation of the blank and $\mathrm{s}$ is the slope of the regression line [18]. Limit of detection (LOD) and limit of quantification (LOQ) were found $0.02 \mu \mathrm{g} / \mathrm{ml}$ and $0.06 \mu \mathrm{g} / \mathrm{ml}$ respectively. The conditional molar absorptivity of the product formed was found to be $5.379 \times 10^{4} \mathrm{~L} . \mathrm{mol}^{-1} . \mathrm{cm}^{-1}$.

\section{Accuracy and Precision}

To evaluate the accuracy and precision of the method, a pure drug solution was analyzed at three different concentrations, each determination being repeated six times the relative error (\%) and relative standard deviation (\%) values were summarized in Table (1). From Table (1), it is clear that the relative error of less than $1.9 \%$ and the method was found to be precise with RSD value not more than $1.8 \%$. for a better picture of reproducibility, a series of experiments were performed in 
which the standard drug solution was determined at three different levels each day for six days, with all solutions being prepared a fresh each day. The day-to-day relative standard deviation values were in the range of $0.8-1.8 \%$ and represent the best appraisal of repeatability of the proposed method.

Table(1): Accuracy and precision of the method

\begin{tabular}{|c|c|c|}
\hline Tolnaftate taken, $\boldsymbol{\mu g} / \mathbf{2 5 m l}$ & $\mathbf{E}_{\mathbf{r}} \mathbf{( \% )} \mathbf{~}^{\mathbf{a}}$ & $\mathbf{R S D}^{\mathbf{a}} \mathbf{\%}$ \\
\hline 10 & 1.2 & 1.3 \\
\hline 30 & 1.5 & 1.7 \\
\hline 50 & 1.8 & 1.5 \\
\hline
\end{tabular}

a: Mean of six determinations

\section{Effect of interferences}

The interfering effect of foreign species often accompanied with tolnaftate in the pharmaceutical preparations were studied by adding different amounts of foreign species to $30 \mu \mathrm{g} \backslash 25 \mathrm{ml}$ of tolnaftate in solution and the recommended procedure for the determination of tolnaftate was followed. The species are considered to interfere seriously if they cause a change of more than $2 \%$ in the absorbance obtained for tolnaftate a lone [19]. It was observed that the betamethazone 17-valerate, gentamycine sulphate and clioquinol don't interfere with determination method at levels found in the dosage form cited in Table(2) so that the selectivity of method is very good.

Table [2]: Determination of tolnaftate in presence of excipients.

\begin{tabular}{|l|l|l|}
\hline Excipients & Amount taken, $\mu \mathrm{g}$ & Average recovery*, \% \\
\hline Betamethazon 17-valerate & 30 & 100.05 \\
\hline Gentamycine sulphate & 60 & 100.0 \\
\hline Clioquinol & 50 & 100.08 \\
\hline
\end{tabular}

* Average of seven replicate analyses.

\section{Analytical applications}

The proposed method was satisfactorily applied to the determination of tolnaftate in its pharmaceutical formulations. The results of the assay of the pharmaceutical formulations revels that there was closed agreement between the results obtained by the proposed method and the label claim. The results were also compared statistically by student $\mathrm{t}$-test and by the variance ratio F-test with those obtained by official method [11] at 95\% confidence level. The calculated t- and Fvalues did not exceed the theoretical values indicating that there was no significant differences between the precision of the proposed and official method as cited in Table( 3 ).

Table(3): Determination of tolnaftate in pharmaceutical formulations 


\begin{tabular}{|c|c|c|c|l|l|}
\hline $\begin{array}{c}\text { Pharmaceutical } \\
\text { formulations(NDI) }\end{array}$ & $\begin{array}{c}\text { Label } \\
\text { amount, mg }\end{array}$ & $\begin{array}{c}\text { Official } \\
\text { method [11] }\end{array}$ & $\begin{array}{c}\text { Proposed } \\
\text { method }^{*}\end{array}$ & $\begin{array}{l}\text { F- } \\
\text { value }\end{array}$ & $\begin{array}{l}\text { t- } \\
\text { value }\end{array}$ \\
\hline Quadreem cream & $10 \mathrm{mg} / \mathrm{gm}$ & 9.98 & 9.96 & 1.02 & 1.14 \\
\hline Topical solution & $10 \mathrm{mg} / \mathrm{ml}$ & 9.94 & 9.95 & 1.06 & 1.95 \\
\hline
\end{tabular}

"Mean value of ten determinations

$\mathrm{t}$ values $(\mathrm{n}=10$, at $95 \%$ confidence level tabulated value 2.101$)$.

$F$ values $\left(n_{1}-1\right.$ and $n_{2}-1=9$, at $95 \%$ confidence tabulated value 3.18$)$.

\section{Conclusion}

The proposed method was simple, accurate, precise, sensitive and low economical cost. Furthermore, the proposed method doesn't require elaboration of procedures, which are usually associated with chromatographic methods. The proposed method could be applied successfully for determination of tolnaftate in pure form as well as in different dosage forms.

\section{Acknowledgments}

The first author wishes to express gratitude to his former company [The State Company of Drug Industries and Medical Appliance (NDI) Nineveh - Iraq for providing gift samples of tolnaftate standard material and pharmaceutical preparations

\section{References}

1) O’Neil M. J. "The Merck Index", 14th Edn. Merck and Co. Inc., Whitehouse Station, NJ; 2006, 193-194 and 1636.

2) Sean C. Swetman "Martindale" The complete Drug References, 35th Edn., Pharmaceutical press London,2007.p.494.

3) The pharmaceutical codex, 11, Edn., the pharmaceutical press. London. 1979, p 951.

4) Delgado J. and Remer W. "Text Book of Organic Medical and Pharmaceutical Chemistry" 10 th Edn., Ausolters Kluwors company, Philadepha,1998, p.191.

5) Chandra N. and Sanjib B. "A Validated simultaneous RP-HPLC method for determination of betamethasone dipropionate and tolnaftate in combined semisolid formulation" International Journal of Chem Tech Research, 2009..1(3), 671-674.

6) Safeena S., Suhail A. and Ahmad S. "Liquid chromatographic technique for stability indicating analytical method development and validation of salicylic acid and tolnaftate in pharmaceutical ointment by high performance" International Journal of Scientific and Research Publications, 2012,2( 12), 1-6. 
7) Tomake U., Olgakorny O., Audrius M. and Vitalis B. "Assy of tolnaftate in human skin samples after in vitro penetration studies using HPLC" Acta Poloniaen Pharmaceutica Drug Research, 2010, 67(4), 327-334.

8) Thompson, R. D., and Carlson, M., Liquid chromatographic determination of tolnaftate in commercial products. J. Assoc. Off. Anal. Chem. 1991, 74(4), 603-607.

9) Dash, A. K., A liquid chromatographic method for the determination of tolnaftate in pharmaceutical formulations. J. Pharm. Biomed. Anal., 1993, 11(9), 847-853.

10) Dhananjay B., Shashikant B. and Madhukar R. "A simple HPTLC determination of tolnaftate in topical solution" Journal of Planar Chromatography,2008, 4, 283-287.

11) The United State Pharmacopeia Convention, Inc, 33-NF 28, 2010, P.4968.

12) British Pharmacopoeia, 2013,volume 1: p.2245.

13) Sastry P., Raoj S. and Krishna R.; Spectrophotometric for the determination of tolnaftate;Talanta 1993,40,571-576.

14) Khshaba Y., El.Shabouri R., Emara M. and Mohammed $M$. "Analysis of some antifungal drug by spectrophotometric and spectroflurimetric method in different pharmaceutical dosage forms" Journal of Pharmaceutical and Biomedical Analysis, 2000, 22, 363-376.

15) Nief R. and Thair T. "Indirect spectrophotometric determination of tolnaftate in pharmaceutical preparations" Journal of Education and Science, 2009, 22(2), 9-18.

16) Tang B., Wang X., Wang G. and Chem Z. "Highly sensitive and selective spectroflurimetric determination of tolnaftate through the formation of ternary complex of B-naphthol/B-cyclodextrin/ionic surfactant system" Talanta 2006,69,113-120.

17) Kolthoff I., Belcher R., Stenger V. and Matsnyama G. "Volumetric Analysis" volume III, Interscience Publishers, New York, 1957,p.37.

18) A. Shrivastava and V. Gupta ;Methods for the determination of limit of detection and limit of quantitation of the analytical methods, Chronicles of Young Scientists, 2011, 2(1), 21-25.

19) Hung S. Ch., Qu C. L. and $\mathrm{Wu} \mathrm{S}$. Sh., "Spectrophotometric determination of uranium with 2-(3,5) dibromo -2- pyridylazo -5diethylaminophenol in the presence of anionic surfactant "Talanta, 1982, 29, 629-631. 